\title{
HOW TO IMPROVE STUDENTS' COGNITIVE ABILITY?: THE INFLUENCE OF TWO STAY TWO STRAY TYPE COOPERATIVE MODEL ASSISTED BY INNOVATIVE MODULE
}

\author{
Farralia Ramadhani $^{1}$, Yetri ${ }^{2}$, Irwandani ${ }^{3}$ \\ ${ }^{1,3}$ Departement of Physic Education, Universitas Islam Negeri Raden Intan Lampung, Indonesia \\ ${ }^{2}$ Postgraduate Program, Universitas Islam Negeri Raden Intan Lampung, Indonesia \\ *Corresponding author: liaramadhanifisika@yahoo.com
}

\begin{tabular}{|c|c|}
\hline Article Info & ABSTRACT \\
\hline Article history: & This study aims to see the effect of using the two stay two stray \\
\hline & del assisted by an innovative module on the cognitive \\
\hline Received: April 04, 2021 & learning outcomes of students on the topic of simple machines. This \\
\hline Accepted: June 05, 2021 & quantitative study used a quasi-experimental design with a pretest- \\
\hline Published: July 31, 2021 & $\begin{array}{l}\text { posttest control group design. This study consisted of } 2 \text { classes, } \\
\text { class VIII A as the experimental class and class VIII B as the control }\end{array}$ \\
\hline Keywords: & class. The results showed that the average of the cognitive test of \\
\hline Cognitive ability & experimental class was 80.00 and the control class was \\
\hline Module & $\begin{array}{l}\text { The results of data processing using the Mann Whitney test with a } \\
\text { sig level of } 0.05 \text { revealed that the results of sig. } 2 \text { tailed were } 0.000 \text {, }\end{array}$ \\
\hline Two-stay-two-stray model & $\begin{array}{l}\text { less than } 0.05 \text {, which means that there is a difference in the posttest } \\
\text { average value of students' cognitive learning outcomes in the } \\
\text { control and experimental classes. }\end{array}$ \\
\hline
\end{tabular}

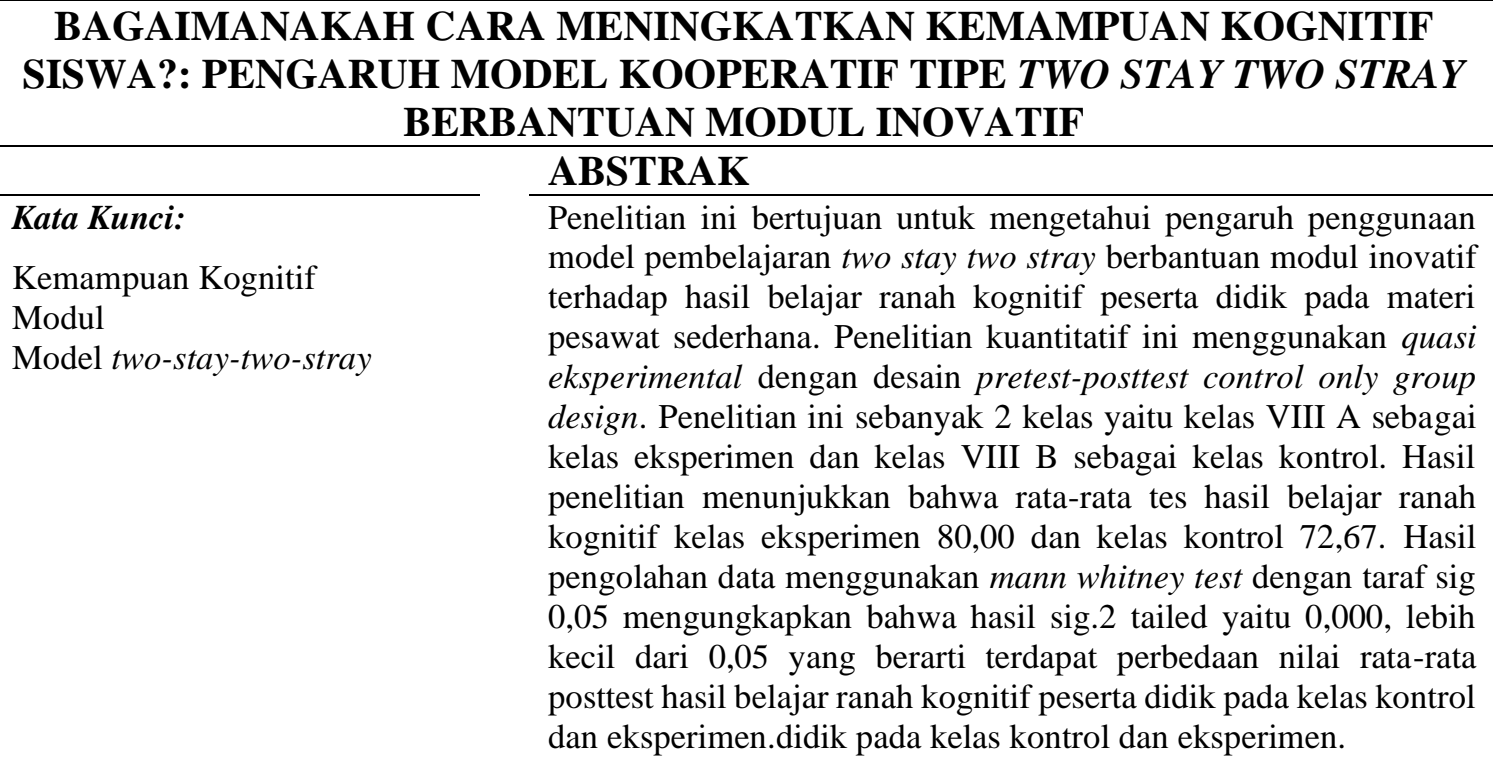

(C) 2021 Unit Riset dan Publikasi Ilmiah FTK UIN Raden Intan Lampung

\section{INTRODUCTION}

Learning is all actions that are formed to support the process of student learning activities, by predicting ongoing events [1]. The learning process that leads to increasing students' thinking skills is carried out by predicting the cognitive development of students, so that teachers must master knowledge better [2]. Cognitive abilities are the basis for 
assembling knowledge, attitudes, and motor skills to achieve superior competencies in accordance with learning objectives [3].

Natural Science is a rational and objective knowledge that studies natural phenomena factually, either reality or the concept of a phenomenon [4]. Natural science is one of the subjects in school, which can provide an important role and experience for students [5]. The purpose of learning natural science is to develop students' cognitive, psychomotor affective, develop students' creativity, and train students to think critically [6]. Science learning in Indonesia is a very important lesson because it is a basic lesson taught since elementary school. Science learning teaches students to learn to find out about the structure of nature systematically. Learning science makes students able to master knowledge about facts, concepts, and natural principles [7].

Every teacher should be able to create effective learning patterns so that students have a high desire to learn and focus on learning. Learning patterns or learning models are proven to have a strong influence in creating a positive learning atmosphere [8]. The approaches applied in science learning have to combine process experience with product understanding in the form of direct experience. Science learning is very important to be directed to the process of solving a preservation of human life in a conducive cultural atmosphere [9].

However, in the reality of learning in schools, in one of the madrasas in Sukarame, Bandar Lampung, the results of observations of 7th-grade students and interviews with one of the science subject teachers indicate that the learning process still uses the lecture and discussion method that goes one way. One of the cooperative models applied by the teacher is the group investigation (GI) type, cooperative model. The use of the same method or model makes learning boring, so students are not actively involved in learning. As a result, learning objectives become difficult to achieve and student learning outcomes are low, especially in cognitive abilities. This can be seen from the results of the mid-semester exam which shows an average of below 50 or below the minimum standard. The learning resources used in this school are still using worksheets and books from the Ministry of Education and Culture. No teacher has designed their own module yet. In fact, the teacher's design module will be more effective because it is planned, compiled, and made by the teacher and adapts to the needs of students. By providing learning resources that suit student needs, students will become more interested in learning so as to increase student participation in learning. With the increase in student participation, the activity of thinking also increases and it is possible to increase the cognitive abilities of students [10], [11].

One of the learning models that can increase student activity is the two-stay twostray model. The two-stay two-stray model is learning by dividing into groups, then the groups discuss problems and find solutions [12]. In this learning model, the discussion process runs with some group members leaving their group and joining other groups that aim to seek information. While some of the remaining members are tasked with distributing the results of their group work to visiting members. Then the visiting members return to their respective groups and discuss the information they get [13]. The advantages of the two stay two stray learning model are 1) It can be used in all types of subjects and all age levels of students. 2) Learners have a learning experience with all their classmates, not only with group members, so they can practice collaboration and communication skills. 3) Develop positive character in students by increasing self-confidence and respect for others. 4) Improve the ability to express opinions. 5) The learning process in the classroom becomes more memorable so that student learning outcomes can increase [14]. 
The syntax of the cooperative model type two stay two stray is shown in Figure 1 [15].



Figure 1. The Syntax of the Cooperative Model Type Two Stay Two Stray

In addition to learning models, learning resources are also things that teachers must consider carefully, because learning resources are useful to support the teaching and learning process so that learning objectives can be achieved. Learning resources are everything that can be used by students and educators for learning purposes that aim to increase the effectiveness and efficiency of learning [16]. The module is a book that aims to direct students to learn independently without teacher guidance. The module at least contains the main components of teaching materials. The module used in science learning aims to make students better understand the lesson through independent study [17].

Cognitive ability is the ability of students in the thinking process and the ability of students to solve a problem [18]. Previous research has proven that the two-stay two-stray cooperative learning model can improve students' cognitive learning outcomes [19]. Other research has also proven that the application of the two stay two stray type of cooperative learning model can improve student learning outcomes [20]. However, the two-stay twostray model has never been applied to solve learning problems at the Muhammadiyah Islamic school in Sukarame Bandarlampung. Therefore, this study is here to prove the effect of the two-stay two-stray learning model assisted by innovative module in improving students' cognitive abilities. The Innovative Module referred to in this study is a module that is made by considering the needs of students and adapting to the topics taught

\section{METHOD}

The research method used is a quantitative method. Quantitative method is a research method used to find the effect of certain treatments (treatments) in controlled conditions [21]. The design of this study was a quasi-experimental type of randomized control group only pretest-posttest design. In this design, before being given a treatment, both the experimental group and the control group were given a pretest [22].

This research was conducted at MTs Muhammadiyah Sukarame Bandar Lampung during odd semesters. The population in this study were 8th grade students and the sample of this study was 8 th class $\mathrm{A}$ as the experimental class, totaling 32 students, and class $8 \mathrm{~B}$ as the control class, totaling 30 students.

The sampling technique was carried out by purposive sampling technique. Purposive sampling technique is a sampling technique with certain considerations, not based on strata, groups or random [23]. Data collection techniques used are tests, interviews, and documentation. The test is used to measure students' cognitive abilities. The test was carried out twice, the pretest was a test before being given treatment, and the posttest was a test after being given treatment. The test is in the form of multiple-choice with 25 items, before the test is used, the 25 items are tested to determine the validity, reliability, level of difficulty, differential power, and quality of distractors. After the trial, the questions that can be used for the pretest and posttest were 10 questions.

Cognitive learning outcomes tests follow the cognitive indicators on bloom taxonomy those are: C1 (remember), C2 (understand), C3 (apply), C4 (analyze) related to simple machine topic [24]. 
The data analysis technique in this study uses the $\mathrm{N}$-gain test, which is used to see the increase in the results of the pretest and posttest which is calculated using the average normalized gain [25]. Normality test is used to determine the distribution of data. The normality test was carried out using the Kormogorov-Smirnov test with the SPSS 16 program, if the probability $>0.05$ then the data would be declared normally distributed, and if the probability value was $<0.05$ then the data would be declared to be not normally distributed [26]. Homogeneity test is used to see the homogeneity of the data. The homogeneity test was carried out using the Leneve's test with the SPSS 16 program, the reason for using the Leneve's test method was because this study only compared two variances. The data is said to be homogeneous if the significance obtained is $>0.05$ [27].

The next stage is hypothesis testing, which is to compare two independent groups [28]. Hypothesis testing in this study used a nonparametric test, the Mann Whitney test (Utest) on the SPSS 16 program with a significance level of 5\%. This U-Test is used to test the comparative hypothesis of two independent samples if the data is in ordinal form [29].

\section{RESULTS AND DISCUSSION}

Based on the results of the study, the cognitive abilities of students increased after the implementation of the twostay two stray cooperative model assisted by module. The following graph shows the results of the average pretest and posttest scores from the experimental class and the control class.

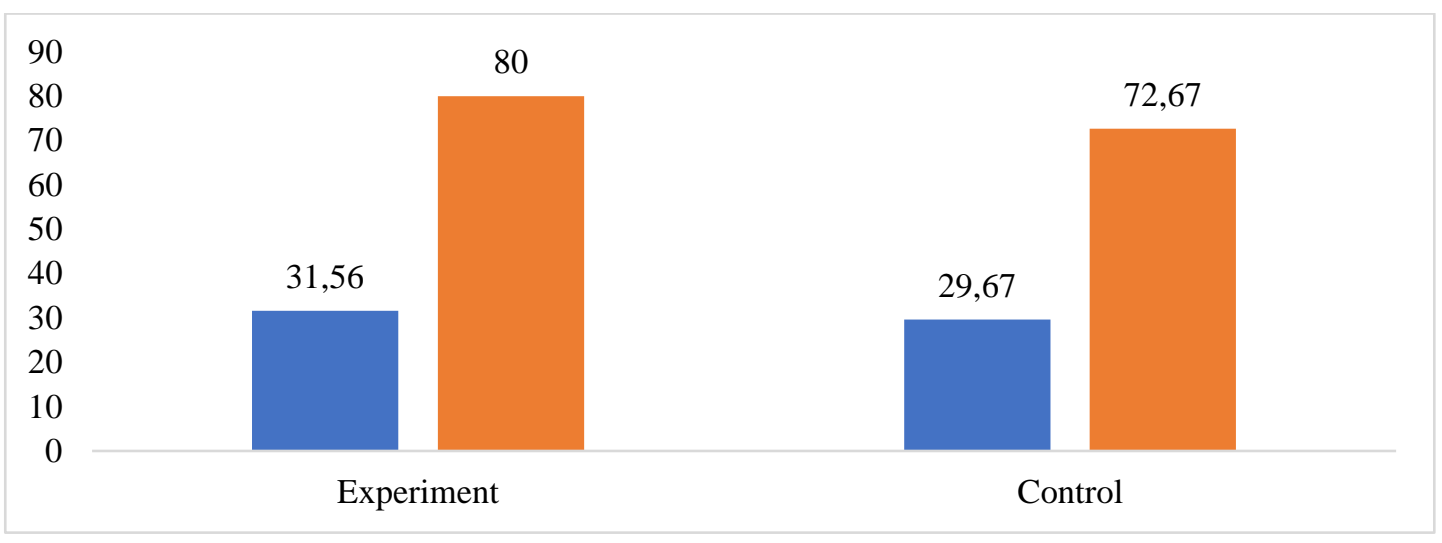

Figure 2. Graph of the Average Pretest and Posttest Scores.

From the graph above, it is known that the average pretest result obtained by the experimental class is 31.56 , and the posttest result is 80 . While in the control class, the pretest result is 29.67 and the posttest is 72.67 . It can be seen that the increase in the experimental class is higher.

The results of the calculation of N-gain using SPSS 16 in the experimental class showed results of 0.71 , while in the control class showed results of 0.61 , so it can be seen that the value of $n$-gain in the experimental class was higher than the value of n-gain in the control class. . This is because learning outcomes in the experimental class are influenced by the use of a two-stay-two-stray cooperative model that is assisted by a module.

In this study, there are 4 aspects of cognitive abilities that are the object of observation. Figure 3 shows a graph of the average cognitive ability of the experimental class and control class students based on the four abilities observed aspects. 


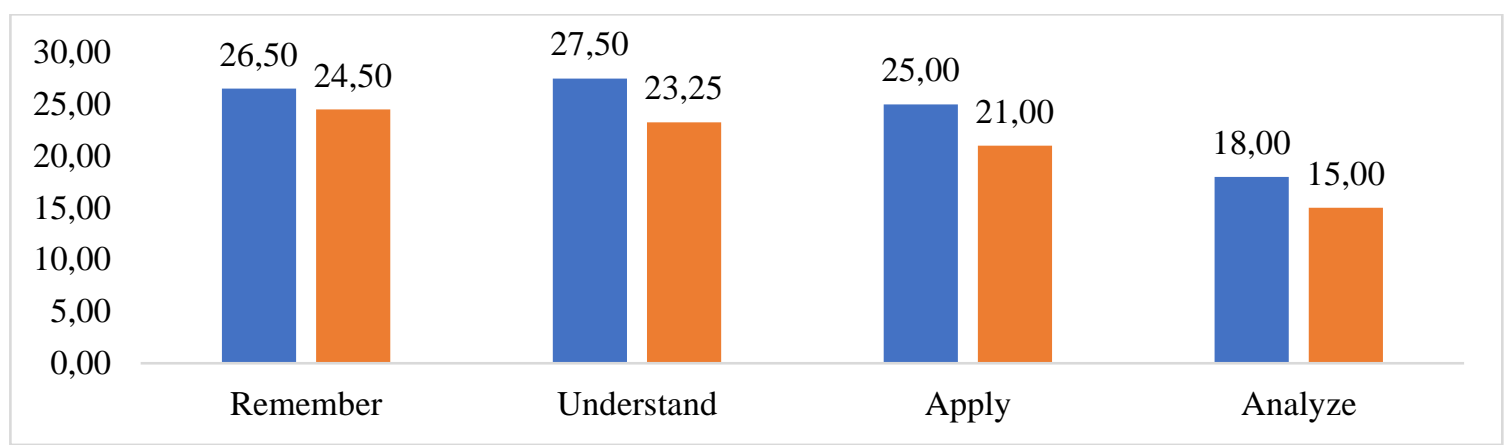

Figure 3. Graph of Increasing the Average Value of Cognitive Abilities

Of the four aspects, namely remember, understand, apply, analyze, there are three aspects that have the highest achievement, the three aspects are :remember, understand, and apply. This is because in cooperative learning with the type of two stay two stray there are stages that lead to these three aspects, precisely in the third stage which is a group activity. At this stage, students study the problems given and discuss these problems with their groups. These stages play an important role in improving the cognitive abilities of students in these three aspects. Students are directed to discuss by dividing groups of 4 students, then in groups, students choose 2 students who stay and 2 students who go to discuss the results of their group discussions to other groups. This serves to increase memory, hone understanding, and review the ability to apply. In general, the results of this study prove that the use of the cooperative model with the type of two stay two stray assisted by innovative modules that are adapted to the topics taught and the needs of students gives different results to students' cognitive abilities.

Before testing the effect of treatment on the cognitive abilities of students, the prerequisite test of data analysis was conducted first. The prerequisite test of data analysis in this study used the normality test and homogeneity test. The normality test used the Kolmogorov-Smirnov test and the homogeneity test used the Leneve's test on the SPSS 16 program. The Kolmogorov-Smirnov test was used because the sample used was $n>50$ samples (62 students). Table 1 shows the results of the normality test calculation with a confidence level of $95 \%(=0.05)$.

Table 1. Normality Test Results

\begin{tabular}{ccc}
\hline & \multicolumn{2}{c}{ Table 1. Normality Test Results } \\
\cline { 2 - 3 } & \multicolumn{2}{c}{ Statistic } \\
\cline { 2 - 3 } & Kolmogorov-Smirnov Test ( Sig $\geq \mathbf{0 , 0 5})$ \\
\cline { 2 - 3 } & Pretest & Posttest \\
\hline Experimental & 0,032 & 0,000 \\
Control & 0,000 & 0,000 \\
Conclusion & & Not normally distributed \\
\hline
\end{tabular}

Based on Table 1, it is known that the pretest and posttest data in the control class are not normally distributed. So that statistical analysis can not be done with parametric tests.

The homogeneity test used was Levene's test on SPSS 16. Table 2 shows the results of the homogeneity test on the pretest and posttest.

Table 2. Homogeneity Test Results

\begin{tabular}{ccc}
\hline & \multicolumn{2}{c}{ Statistic } \\
\cline { 2 - 3 } & \multicolumn{2}{c}{ Leneve's Test ( Sig $\geq \mathbf{0 , 0 5})$} \\
\cline { 2 - 3 } & Pretest & Posttest \\
\hline $\begin{array}{c}\text { Experimental } \\
\text { Control } \\
\text { Conclusion }\end{array}$ & 0,807 & 0,156 \\
\hline
\end{tabular}


Based on Table 2, it can be seen that based on Leneve's test on the pretest value, the Sig value is $0.807>0.05$, meaning that the samples have a homogeneous variance. In Leneve's test, the posttest value is known to be the Sig value of 0.156 , so $0.156>0.05$ means that the samples are proven to be homogeneous. So both pretest and posttest data in the experimental class and control class have homogeneous variance with $\mathrm{Sig}>0.05$.

After knowing that the data is not normally distributed and has a homogeneous variance, a hypothesis test is carried out using the Mann Whitney test in the SPSS 16 program. With a significant level criterion of $=0.05$. Mann Whitney test results are shown in Table 3.

Table 3. Mann Whitney Test Results

\begin{tabular}{ccc}
\hline & Pretest & Posttest \\
\hline Criteria & Sig. (2-tailed) & $<0,05$ \\
Sig. (2-tailed) Value & 0,529 & 0,000 \\
Conclusion & $\mathrm{H}_{\mathrm{o}}$ is accepted & $\mathrm{H}_{\mathrm{a}}$ is accepted \\
\hline
\end{tabular}

Based on Table 3, in the Mann Whitney test, the results of the pre-test showed that the 2-tailed Sig was 0.529, while the 2-tailed Sig was 0.000 for the posttest data. The criteria used are if Sig (2-tailed) $<0.05$ then the treatment has an effect. In the pretest value data obtained Sig 0.529>0.05 means $\mathrm{H}_{\mathrm{a}}$ is rejected and $\mathrm{H}_{0}$ is accepted. While the posttest value data Sig $0.000<0.05$ means $\mathrm{H}_{\mathrm{a}}$ is accepted and $\mathrm{H}_{0}$ is rejected. So it can be concluded that there is an effect of the two-stay two-stray cooperative model assisted by an innovative module on the cognitive abilities of students.

Previous research revealed that cooperative learning is believed to be a pedagogical practice to improve the learning process, higher-order thinking styles, social behavior, and concern for students who have different backgrounds, abilities, adjustments, and needs [30]. Based on the results of data analysis, learning outcomes for cognitive aspects in the experimental class are higher than in the control class. This situation is suspected because learning using a two-stay two-stray cooperative model requires all students to be active in discussing understanding concepts and finding solutions to solving problems. Based on previous research, it is known that two-stay-two-stray learning stimulates students' thinking ability to continue working and find solutions [31]. The increase in student learning outcomes occurs because each group member has their respective activities and roles in doing the tasks in the module. Previous research has also proven that innovative modules or modules that are made based on needs have a role in improving cognitive abilities [32].

The cognitive domain according to Bloom can be achieved in learning if learning pays attention to unique characteristics [33]. In this case, it is important to allow students to take part in learning, therefore the use of innovative modules will be very helpful, in addition, every student who plays an active role in group discussions can also have a positive influence. The two stay two stray learning model has an effect on student learning outcomes because through discussion, students exchange information, the more subjects are invited to discuss, the more new information is obtained by students. So that students can analyze and process concepts in more depth. In addition, through an active discussion process, students' communication skills will also be trained [34].

Based on the description above, it can be concluded that the use of a two-stay twostray cooperative model with the help of an innovative module greatly affects the cognitive abilities of students and can be used as an alternative in science learning to improve students' cognitive abilities. The Innovative Module referred to in this study is a module that is made by considering the needs of students and adapting to the topics taught 


\section{CONCLUSION}

Based on the results of the study, it is known that the two stay two stray learning model assisted by an innovative module has a positive influence on learning outcomes in the cognitive domain of students. This can be seen from the average value of $n$-gain in the experimental class 0.71 and the control class 0.61 and the hypothesis test obtained a significance of $0.000<0.05$. So it can be concluded that there is an effect of the two-stay two-stray cooperative model assisted by an innovative module on the cognitive abilities of students. This study provides knowledge for teachers that the two-stay two-stray model assisted by innovative module can be used as an alternative in science learning to improve students' cognitive abilities.

\section{REFERENCES}

[1] S. Latifah, "Pengembangan Modul IPA Terpadu Terintegrasi Ayat-Ayat Al-Qur'an Pada Materi Air Sebagai Sumber Kehidupan," J. Ilm. Pendidik. Fis. Al-Biruni, vol. 4, no. 2, p. 155, 2015.

[2] Y. Aditia, R. Herdhiana, and B. A. Sritumini, "Pengaruh Model Problem Based Learning Terhadap Peningkatan Kemampuan Kognitif Siswa dalam Memahami Konsep Dasar Ilmu Ekonomi," JP2EA J. Pendidik. dan Pembelajaran Ekon. Akunt., vol. 3, no. 2, 2017.

[3] L. A. Sholehah, "Perbedaan Kemampuan Kognitif Siswa Menggunakan Model Pembelajaran Kancing Gemerincing Dan Jigsaw Pada Pembelajaran Tematik Tema 9 Kelas V Sd," J. Pemikir. dan Pengemb. SD, vol. 5, no. 2, 2017.

[4] A. Widi and E. Sulistyowati, Metodologi Pembelajaran IPA. jakarta: Bumi Aksara, 2014.

[5] G. Hamdu and L. Agustina, "Pengaruh Motivasi Belajar Siswa Terhadap Pestasi Belajar Ipa Di Sekolah Dasar,” J. Penelit. Pendidik., vol. 12, no. 1, 2011.

[6] Rini, I. M. Tangkas, and I. Said, "Meningkatkan Hasil Belajar Siswa Melalui Penggunaan Metode Demonstrasi Pada Mata Pelajaran IPA Di Kelas III SDN Inpres Tunggaling," J. Kreat. Tadulako Online, vol. 2, no. 1, 2007.

[7] R. Diani, "Pengaruh Pendekatan Saintifik Berbantuan LKS Terhadap Hasil Belajar Fisika Peserta Didik Kelas XI SMA Perintis 1 Bandar Lampung," J. Ilm. Pendidik. Fis. Al-Biruni, vol. 05, pp. 83-93, 2016.

[8] Nurfaidah, Suprapta, and M. S. L, "Peningkatan Hasil Belajar Dengan Menggunakan Metode Pembelajaran Student Team Learning Modification," J. Pendidik. Fis., vol. 6, no. 1, 2018.

[9] F. E. Wulandari, "Pengaruh Pembelajaran Berbasis Proyek Untuk Melatihkan Keterampilan Proses Mahasiswa," J. Pedagog., vol. 5, no. 2, pp. 247-254, 2016.

[10] M. I. Supiandi and H. Julung, "Pengaruh Model Problem Based Learning (PBL) terhadap Kemampuan Memecahkan Masalah dan Hasil Belajar Kognitif Siswa Biologi SMA," J. Pendidik. Sains, vol. 4, no. 2, 2016.

[11] Z. Oktafiani, "Meningkatkan Aktivitas dan Kemampuan Kognitif dengan Model Pembelajaran Kooperatif Tipe Jigsaw pada Siswa Kelas X SMA Negeri 1 Wedung Tahun Pelajaran 2016/2017," JP3 (Jurnal Pendidik. dan Profesi Pendidik), vol. 3, 2017.

[12] A. Suprijono, Cooperative Learning Teori dan Aplikasi Paikem. Yogyakarta: Pustaka Pelajar, 2015.

[13] A. Sari and M. P. Azmi, "Penerapan Model Kooperatif Tipe Two Stay Two Stray ( Tsts ) Terhadap Kemampuan Komunikasi Matematis," J. Cendekia J. Pendidik. Mat., vol. 2, no. 1, 2018. 
[14] S. Syamsiah and G. Gunansyah, "Penerapan Model Pembelajaran Kooperatif Tipe Two Stay Two Stray Pada Mata Pelajaran Ips Untuk Meningkatkan Hasil Belajar Siswa Kelas Iv A Sdn Simomulyo 8 Surabaya," JPGSD, vol. 2, no. 1, 2014.

[15] R. Astarina, Suharto, and A. I. Kristiana, "Penerapan Model Pembelajaran Kooperatif Teknik Two Stay Two Stray (Tsts) Berbantuan Cd Interaktif Untuk Meningkatkan Hasil Belajar Matematika Pokok Bahasan Tabung Dan Kerucut Siswa Kelas Ix D Smp Negeri 6 Situbondo Tahun Ajaran 2013/2014," Kadikma, vol. 6, no. 1, 2015.

[16] I. Permatasari, Suparmi, and S. Widha, "Pengembangan Modul Fisika Sma / Ma Berbasis Siklus Belajar 7e ( Learning Cycle 7e ) Berbantuan Video Pada Materi Fluida Dinamis Sebagai Upaya Meningkatkan Motivasi Belajar Siswa Kelas XI," J. Inkuiri, vol. 5, no. 2, 2016.

[17] D. Purnomo, I. Meti, and K. Puguh, "Pengaruh Penggunaan Modul Hasil Penelitian Pencemaran Di Sungai Pepe Surakarta Sebagai Sumber Belajar Biologi Pokok Bahasan Pencemaran Lingkungan Terhadap Hasil Belajar Siswa," J. Pendidik. Biol., vol. 5, no. 1, 2013.

[18] Selvianti, M. S. Ali, and Helmi, "Pengaruh Model Pembelajaran Kooperatif Tipe Two Stay Two Stray Terhadap Aktivitas dan Hasil Belajar Fisika Peserta Didik Kelas XII A SMAN1 Lilirilau 1," J. SAINS DAN Pendidik. Fis., vol. 11, no. 1, 2015.

[19] N. Ismawati and N. Hindarto, "Penerapan Model Pembelajaran Kooperatif dengan Pendekatan Struktural Two Stay Two Stray untuk Meningkatkan Hasil Belajar Siswa Kelas X SMA,” J. pendidkan Fis. Indones., vol. 7, 2011.

[20] A. Z. Lapohea, "Penerapan Model Pembelajaran Kooperatif Tipe Two Stay Two Stray untuk Meningkatkan Hasil Belajar Siswa Pada Materi Logika Matematika," J. Elektron. Pendidik. Mat. Tadulako, vol. 1, no. 2, 2014.

[21] Sugiyono, Metode Penelitian \& Pengembangan Research and Development. Bandung: Alfabeta, 2015.

[22] Yuberti and A. Saregar, Pengantar Metodologi Penelitian Pendidikan Matematika Dan Sains. 2017.

[23] M. Rukaesih A. and C. Ucu, Metodologi Penelitian Pendidikan. Jakarta: Rajawali Pers, 2015.

[24] F. . Wibowo and A. Suhandi, "Penerapan Model Science Creative Learning (SCL) Fisika Berbasis Proyek untuk Meningkatkan Hasil Belajar Kognitif dan Keterampilan Berpikir Kreatif," J. Pendidik. IPA Indones., vol. 2, no. 1, 2013.

[25] R. Erina and H. Kuswanto, "Pengaruh Model Pembelajaran Instad Terhadap Keterampilan Proses Sains Dan Hasil Belajar Kognitif Fisika Di SMA," J. Inov. Pendidik. IPA, vol. 1, no. 2, p. 2478, 2015.

[26] I. Gunawan, Pengantar Statiska Inferensial. Jakarta: Raja Grafindo Persada, 2016.

[27] Rojihah, L. A. Akhrani, and N. Hasanah, "Perbedaan Political Awareness Dilihat Dari Peran Gender Pemilih Pemula," J. MEDIAPSI, vol. 1, no. 1, 2015.

[28] P. Suparmo, Metode Penelitian Pendidikan Fisika. Yogyakarta: Universitas Sanata Dharma, 2010.

[29] Sugiyono, Statiska untuk Penelitian. Bandung: Alfabeta, 2007.

[30] R. Rusdiana, "Penerapan Metode Pembelajaran Two Stay Two Strayn (TS-TS) untuk Meningkatkan Motivasi dan Hasil Belajar Mata Pelajaran Ekonomi Siswa Kelas XI IPS SMA Negeri 1 Depok Tahun Ajaran 2016/2017,” J. Pendidik. dan Ekon., vol. 6, no. 3, 2017.

[31] L. S. Asna, Sugiharto, and E. Susanti, "Efektivitas Metode Pembelajaran Two Stay Two Stray (TSTS) Menggunakan Media LKS Dilengkapi Molymod Terhadap 
Prestasi Belajar Siswa Pada Materi Pokok Ikatan Kimia Kelas XI IPA SMA Negeri 1 Mojolaban Tahun Ajaran 2013/2014," J. Pendidik. Kim., vol. 3, no. 1, 2014.

[32] E. Purwaningsih, E. Ariyati, and R. G. P. Panjaitan, "Penerapan Model Pembelajaran Kooperatif Tipe Two Stay Two Stray Terhadap Hasil Belajar dan Sikap Ilmiah Siswa Pada Materi Keanekaragaman Hayati di Kelas X MAN 1 Pontianak," J. Pendidik. Mat. dan IPA, vol. 5, no. 2, 2014.

[33] D. Insyasiska, S. Zubaidah, and H. Susilo, "Pengaruh project Based Learning Terhadap Motivasi Belajar Kreativitas Kemampuan Berpikir Kritis dan Kemampuan Kognitif Siswa Pada Pembelajaran Biologi,” J. Pendidik. Biol., vol. 7, no. 1, 2015.

[34] Q. A. Rohmana, N. Widodo, and L. Kapti, "Penerapan Model Pembelajaran TSTS (Two Stay Two Stray) Dipadu Picture \& Picture untuk Meningkatkan Keaktifan dan Hasil Belajar Materi Jaringan Hewan Pada Siswa Kelas XI SMA,” J. Pendidik., vol. 1, no. 10, pp. 2071-2075, 2016. 